\title{
Corn and Soybean Responses to Two Tillage Systems in a Cool Growing Season
}

\author{
Jesper K. V. Nielsen'1, Howard J. Woodard ${ }^{2}$ \\ ${ }^{1}$ Carrington Research Station, North Dakota State University, Carrington, ND, USA \\ ${ }^{2}$ Plant Science Department, South Dakota State University, Brookings, SD, USA \\ Email: NDSU.Carrington.REC@ndsu.edu, Howard.Woodard@sdstate.edu
}

Received 30 June 2015; accepted 3 August 2015; published 6 August 2015

Copyright (C) 2015 by authors and Scientific Research Publishing Inc.

This work is licensed under the Creative Commons Attribution International License (CC BY). http://creativecommons.org/licenses/by/4.0/

(c) (1) Open Access

\section{Abstract}

A field study in 2014 documented corn and soybean biomass and nutrient responses between conventional-till and no-till tillage systems at Beresford, SD during cooler than normal weather conditions with adequate soil moisture. The overall study was established in 1992. Each treatment plot was monitored weekly from June to August for soil moisture, temperature, and plant growth stages. Biomass was harvested during and at the end of the growing season for yield and nutrient content. Soil moisture measured throughout the early and middle part of the growing season was determined to be sufficient for crop growth, since precipitation was much greater than normal in June $(33.2 \mathrm{~cm})$. However, air temperature was below normal early in the growing season and lowered Growing Degree Days $\left(939^{\circ} \mathrm{C}\right)$ compared to the 30 -year average $\left(139^{\circ} \mathrm{C}\right)$. Soil temperatures (5 cm depth) were not significant between tillage treatments in the corn plots during the growing season for 12 observation dates (range $16.3^{\circ} \mathrm{C}-28.0^{\circ} \mathrm{C}$ ). Plant growth was not significantly different between tillage treatments, reflecting the lack of soil temperature differences $(5 \mathrm{~cm}$ depth) between tillage treatments. The mid-season plant tissue and crop residue at harvest nutrient content $(P, K$, and $\mathrm{Zn})$ were not significant between tillage treatments. Corn grain yields were $\mathbf{1 0 . 3}$ $\mathrm{T} \cdot \mathrm{ha}^{-1}$ and $10.1 \mathrm{~T} \cdot \mathrm{ha}^{-1}$ for conventional tillage and no-till, respectively. Soybean grain yields were 3.9 $\mathrm{T} \cdot \mathrm{ha}^{-1}$ and $3.3 \mathrm{~T} \cdot \mathrm{ha}^{-1}$ for conventional tillage and no-till, respectively. These results would more than likely have been much different in a warmer growing season, when soil temperature and moisture differences between tillage treatments would likely stimulate crop growth in the conventional-tilled soil. This would have also increased nutrient uptake and grain yield levels to greater degree than observed in this study.

\section{Keywords}

Tillage, Corn, Soybean 


\section{Introduction}

Tillage implementation for corn and soybean production depends on agronomic, soil, and economic issues involved. A study in Southern Nebraska showed that corn grain yield was greatest with a rotation-chisel-plow system compared to disk, no-tillage, and ridge-tillage systems in years with average temperature and moisture [1]. Corn grain yield was greater for a no-till system in dry, wet and warmer years. Soybean grain yield was not different among tillage systems in years with average temperature and moisture. Soybean grain yield was greater for a chisel plow system in dry years. Soybean grain yield was greater for a no-till system in warmer and wet years. Furthermore, in extremely hot and dry years, corn and soybean grain yield was greater in the no-till system.

A study in Michigan discussed the effects of no-till corn from wheat root shoot residue (WRSR), no wheat residue (NWR), and wheat root residue treatments (WRR) [2]. The WRSR treatments were greater in soil moisture content, while soil in the NWR and WRR treatments had a faster drying rate. The WRSR treatments resulted in lower soil temperature and less fluctuation from day and night compared to the NRW and WRR due to the insulating effect of the wheat residue on the soil surface.

A study in China showed that corn grain yield was greatest when planted in a ridge-till system compared to no-till and conventional-till treatments [3]. The moisture depletion from ridge-till compared to no-till was not significantly different at two sites. Soil moisture reduction from conventional-till was significantly lower at one site compared to no-till.

A study in Central Mexico showed that increasing residue resulted in greater soil moisture content through the growing season [4]. Ponding time (of surface water) and corn yield increased with the zero-till treatment when crop residue was maintained on the field. Moisture depletion was greatest in conventional-till with or without residue and no-till treatment without residue.

A study in Washington showed that soil moisture was significantly greater with no-till compared to the sweep-till treatment which had less residue retention and less evaporation near the soil surface [5]. Lower temperature fluctuations occurred in the no-till compared to the sweep-till treatment for which more dark soil was exposed to the sun compared to no-till. The temperature of soils with greater water content was more difficult to change since it has a higher heat capacity than dry soils. A study in Iowa showed that corn grain yield had no significant difference between strip-till, chisel-plow and no-till treatment [6]. The same trend was observed for throughout the soil profile.

A study in Northeast China showed that soil moisture depletion in no-till was lower compared to reduced-till and conventional-till treatment, especially in the beginning and late season [7]. Soil moisture depletion was greater in reduced-till and conventional-till treatment. The increased soil moisture content from no-till resulted in an increase in soybean grain yield but a decrease in corn grain yield. A study in North Dakota showed that corn grain yield for no-till was significantly lower than the strip-till treatment. However, grain yields in conventional-till were not significantly different from the other two tillage treatments [8].

In summary, these research studies showed that crop residue cover not disturbed by tillage resulted in retention of greater soil moisture content and reduced temperature fluctuation compared to tilled soils. Soil moisture content decreased because of increased evaporation and soil temperature fluctuated more throughout the day in conventional-till. Corn grain yield also seemed to decrease with no-till and increase with conventional till treatment. However soybean grain yield seemed to increase with no-till and decrease with conventional-till treatment. It can also be concluded that during years of extreme heat and drought, the increased surface residue from no-till may benefit the growing environment by moderating temperature and maintaining moisture levels through the growing season. This would have implications for influencing corn and soybean grain yield in the dryer parts of the soybean production areas of the Great Plains.

The weather in South Dakota can be variable and tillage influences on crop growth and final grain yield can respond strongly to climatic conditions. The objectives for this research were to consider how corn and soybean crops respond to a cooler than normal growing season with adequate available soil water by: 1) Documenting how two tillage systems can influence topsoil soil temperature and soil moisture; and 2) Comparing corn and soybean growth, crop biomass production, and plant nutrient up take among two tillage treatments.

\section{Methods and Materials}

\subsection{Background of Study Site}

The study site was located at the SDSU Southeast Research Farm (SERF) near Beresford, SD at latitude 
$43.04270^{\circ} \mathrm{N}$, and longitude $96.892232^{\circ} \mathrm{W}$. The elevation of the site was $464 \mathrm{~m}$ above sea level. The soil type was an Egan-Trentsilty clay loam which is described as a fine-silty, mixed, and super active mesic Udic Haplustolls [9]. The field site had a slope of less than $2 \%$ and slopes from northeast to southwest.

\subsection{Experimental Design}

The field study began in 1992 when tillage treatments of conventional-till (CT) and no-till (NT) were established for corn and soybean in rotation. The plot dimensions for the soybean crop were $22 \mathrm{~m}$ wide by $100 \mathrm{~m}$ long. The treatments of tillage and crop were assembled as a randomized complete block with three replications. The CT system for corn production consisted of fall disk and chisel-plow operation followed by a spring fieldcultivation operation. However, for soybean production only a disking or field cultivation was performed in the spring.

\subsection{Field Preparation}

In spring 2014, fertilizer potassium was surface-applied as potash (0-0-60) at the rate of $240 \mathrm{~kg} \mathrm{~K} \mathrm{ha}^{-1}$ to both crops with a broadcast application before the tillage operation. Nitrogen was applied to the corn plots before planting as surface application of urea-ammonium-nitrate solution (28-0-0) at a rate of 550 liters ha ${ }^{-1}$ to provide $220 \mathrm{~kg} \mathrm{~N} \mathrm{ha}^{-1}$ with drop nozzles as a pre-plant application for both tillage systems. Corn (hybrid PIOO193AM) was planted at the rate of 71,000 seeds $\mathrm{ha}^{-1}$ in mid-May. Soybean (variety AG2135) was planted at the rate of 330,000 seeds $\mathrm{ha}^{-1}$ in late May in $27 \mathrm{~cm}$ rows for all treatments.

\subsection{Soil Measurements}

Soil cores were removed from the 0 - $15 \mathrm{~cm}$ depth randomly within each plot area between rows at the beginning of the growing season from each treatment plot. The soil was dried and ground to prepare for analysis at the SDSU soil testing lab using standard procedures [10]. Soil particle analysis was determined by the hydrometer method [11]. The organic matter was determined by the Loss-On-Ignition (LOI) method based on [12]. Soil pH was determine by the $\mathrm{pH}$-electrode method based on [13]. Soil nitrate analysis was determined by the Nitrate Electrode method based on [10]. Soil orthophosphate-P analysis was extracted by the Olsen-P methods based on [14] and was determined colori metrically based on [15] Soil-K analysis was extracted by the Ammonium Acetate method and determined by the Atomic absorption based on [16]. Soil-Zn was extracted by DTPA extraction and determined by the Atomic adsorption method based on [17].

\subsection{Plant Measurements}

The plant growth stage rating was documented weekly from June to August, as an average for each measurement in which three plants per plot were selected. Corn plant samples were collected during the growing season from at least four to five rows from the border of the plots. Within those rows, the middle three plants that were most representative of the whole plot were harvested.

\subsection{Soil Measurement}

Soil temperature and moisture were measured on the same day and time of day on a weekly basis. Soil moisture content was measured at a $5 \mathrm{~cm}$ soil depth with a model Field scout TDR 300 Soil Moisture Meter Item \# 6430f3, (Spectrum Technologies, 3600 Thayer Court, Aurora, IL 60,504). Raw moisture measurements were calibrated according to actual volumetric water content measurements determined from another experiment (data not shown). Soil temperature was measured at a two in. depth with a model HH21 Microprocessor Thermometer, Type J-K-T Thermocouple, $\Omega$-OMEGA (OMEGA Engineering, INC. One Omega Drive, P.O. Box 4047, Stamford, Connecticut 06907-0047).

Ten whole above-ground corn plants were sampled at the V6 [18] growth stage and from the corn ear leaf at tasseling (R1) stage. Ten plants were collected from each of two rows. Plant samples were oven dried and ground. Plant samples were prepared by microwave digestion [19] and analyzed for total nitrogen (N), phosphorus (P), potassium (K), and zinc (Zn).

Total above-ground soybean plant tissue was sampled at the R1 [18] growth stage along a one-meter length of 
row from the second row of the plot. Samples were oven dried, ground and analyzed for total N, P, K, and Zn and analyzed with the same analytical methodology used for corn sample analysis.

Corn and soybean grain was harvested by small plot combine after reaching physiological maturity along the entire length of the treatment plots from the middle of the plot. Grain was weighed and analyzed for moisture content and test- weight. Grain yields were estimated on an acre basis. Grain samples were prepared for analysis as the tissue was before. Data were entered into an Excel spreadsheet and analyzed using R software and using the "Agricolae" package [20].

Corn and crop soybean residue was collected from a $6.5 \mathrm{~m}^{2}$ surface area after grain harvest for all treatment-replications. The crop residue was weighed in the field then a subsample was dried to determine biomass harvest weight. The biomass was prepared for analysis $(\mathrm{P}, \mathrm{K}$, and $\mathrm{Zn})$ as for the plant tissue analysis. Grain yield was also analyzed for the nutrient content as previously described.

\section{Results and Discussion}

\subsection{Climatic Parameters}

The average mean air temperature was just slightly below normal for May and June compared to the 30-year average, but $2.6^{\circ} \mathrm{C}$ below normal for July, and $1.1^{\circ} \mathrm{C}$ below normal for August (Table 1). Lower mean air temperatures were reflected a lower cumulative Growing Degree Days (GDD) of $20\left({ }^{\circ} \mathrm{C}\right.$ ) lower than normal for May, $62\left({ }^{\circ} \mathrm{C}\right)$ lower than normal for June, $85\left({ }^{\circ} \mathrm{C}\right)$ lower than normal for July, and $68\left({ }^{\circ} \mathrm{C}\right)$ lower than normal for August. The four-month growing season cumulative GDD was $939\left({ }^{\circ} \mathrm{C}\right)$ which was $20 \%$ below the normal GDD of $1173\left({ }^{\circ} \mathrm{C}\right)$. Lower than normal GDD in June and July during critical corn biomass and ear development stage, probably impacted final corn grain test weight and yield. Cooler than normal air temperatures in the growing season most likely decreased soil evaporation as well. The monthly precipitation was slightly below normal for May, but $23.2 \mathrm{~cm}$ above normal for June compared to the 30-year average. The four-month cumulative precipitation of $48.5 \mathrm{~cm}$ was $38 \%$ greater than for the 30 -year average of $35.0 \mathrm{~cm}$. Most of this difference was attributed to higher than normal rainfall received in June. There was adequate soil moisture for crop growth at the early part of the growing season since no plant stresses were observed.

\subsection{Physical and Chemical Properties}

Soil organic matter content ranged from $4.80 \%$ to $4.97 \%$ and soil $\mathrm{pH}$ ranged from 5.40 to 5.47 among treatment replications which was very narrow (Table 2). The extractable or tho-P ranged from 11.7 to $14.4 \mathrm{ppm}$. These levels were determined to have a "medium" status for corn [21]. The extractable potassium was determined to be at a "very high" status for both corn and soybean across all treatments. This high level reflects the addition of fertilizer $\mathrm{K}$ added to all treatment plots in the previous spring before planting in order to minimize any $\mathrm{K}$ stress to the growing crops. Extractable soil zinc was determined to be "very high" for corn and soybean across all treatments.

\subsection{Soil Temperature}

The mean soil temperature for corn with conventional-till was generally greater in the early part of the growing season (June 6: $28.6^{\circ} \mathrm{C}$ ) compared to the late growing season with (August 21: $23.3^{\circ} \mathrm{C}$ ) (Table 3). In the no-till treatment, the mean soil temperature in corn was slightly lower than the conventional-till treatments in the early part of the growing season (June 6: $24.3^{\circ} \mathrm{C}$ ) and in the later part of the growing season (August 21: $25.4^{\circ} \mathrm{C}$ ). In each of the observation dates, there was no statistical significance (N.S.) in the soil temperature between tillage treatments. It was expected that the residue cover of no-till treatment to reflect the sun's energy and result in lower soil temperatures than average compared to the 30 -year average. However similar soil temperatures between tillage treatments were observed during this growing season.

The mean soil temperature for soybean with conventional-till was generally higher in the early part of the growing season (June 6: $26.1^{\circ} \mathrm{C}$ ) compared to the late growing season with (August 21: $23.7^{\circ} \mathrm{C}$ ) (Table 3). In the no-till plots, the soil temperature was slightly lower than in the tilled treatments in the early part of the growing season (June 6: $23.9^{\circ} \mathrm{C}$ ) but similar to the tilled treatments in the later part of the growing season (August 21: $22.8^{\circ} \mathrm{C}$ ). Only for four of the five observations between June 14 and July 10 were the soil temperature differences statistically greater for the conventional-tilled treatments compared to the no-till treatments. 

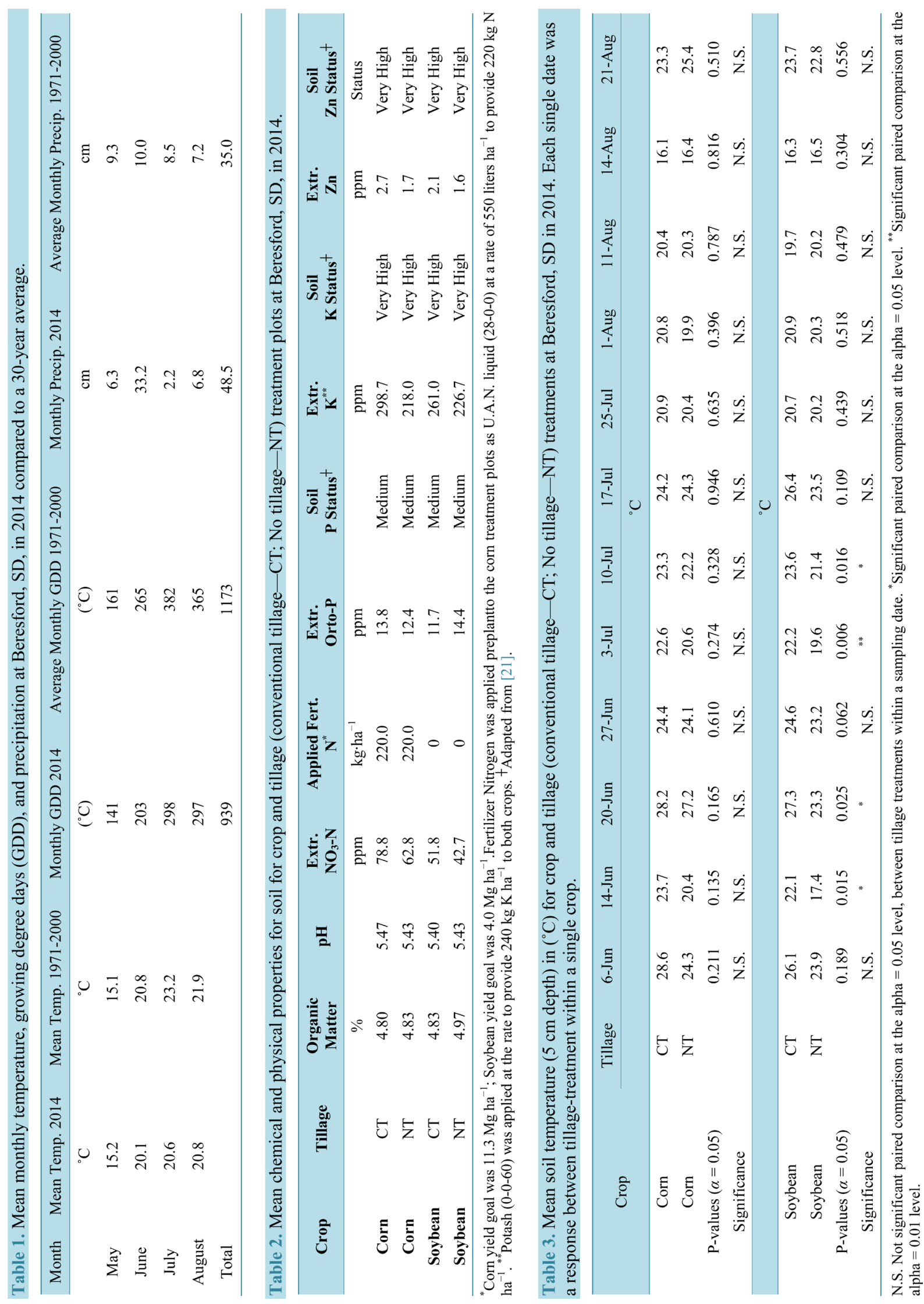


\subsection{Soil Moisture}

The calculated mean soil moisture content for corn for the tillage treatments was generally adequate for the early part of the growing season (June 3: $30.2 \%$ vs. $28.9 \%$, respectively, for CT vs. NT) as well in the later part of the growing season (August 21: $28.1 \%$ vs. $28.0 \%$, respectively) (Table 4). The mean soil moisture for soybean for both conventional-till and no-till treatment was generally adequate for the early part of the growing season (June 3: $29.0 \%$ vs. $31.6 \%$ respectively, for CT vs. NT) and was slightly greater for the conventional-till compared to the no-till treatment in the late growing season (August 21: 31.7\% vs. 27.5\%, respectively, for CT vs. NT). However for each of the observation dates, there was no statistical significance in the soil moisture (N.S.) between till treatments.

One would expect that the residue cover in the no-tillage treatment to reduce soil evaporation compared to the conventional-till treatment since the residue acted as a barrier to evaporation and reflected the sun's energy. Cooler than normal growing season air temperatures reduced the soil evaporation potential in these treatments. The result was that there was no difference in the soil moisture content between tillage treatments. These results could have been much different in a drier or warmer growing season. Soil moisture content was usually high among tillage treatment. Perhaps higher rainfall in the early part of the growing season reduced nitrogen availability because of leaching. It is also possible that denitrification occurred in these soils (not measured) which was usually wet during the early part of the growing season. This could also have influenced crop growth since available soil $\mathrm{N}$ levels may have been reduced.

\subsection{Plant Growth Stages}

The growth stage for both crops progressed in both tillage systems from the vegetative to the reproductive growth stage from June 3 to August 21 (Table 5). The transition from the vegetative stage to the reproductive stage occurred from July 10 to July 17 for both crops. However, there was no statistical difference in the growth stage progression (N.S.) or between tillage treatments for most dates. Generally the soil temperatures are greater in conventional-till treatments due to greater exposure of the disturbed soil to the sun's energy and the absence of a crop residue surface barrier to reduce evaporation as in no-till. However, tillage had little influence on growth progression.

During a warmer growing season, one would expect that crops growing in the tilled treatments would advance farther compared to the no-till treatments. Slightly higher soil temperatures were observed in the middle of the growing season for the conventional-till plot (Table 3). The result was that the conventional-till plots generally stimulated crop growth somewhat compared to no-till plots. This resulted in a slightly greater advancement in growth stages in the middle of the growing season. But the difference was not statistically significant.

Adequate soil moisture levels together with cooler than normal air temperatures probably lowered the evaporation potential in the conventional-till treatments. This probably slowed growth in the conventional-till treatment and so the crop advanced for both tillage treatments similarly in the early part of the growing season.

\subsection{Plant Tissue Nutrient Level}

The total tissue $\mathrm{P}, \mathrm{K}$, and Zn-nutrient concentration for corn at the V6 stage of growth was sufficient for the conventional-till treatment by $(0.34 \%, 3.3 \%$, and $25.6 \mathrm{ppm})$. The total $\mathrm{P}, \mathrm{K}$, and Zn-nutrient concentration was also sufficient for the no-till treatment by $(0.35 \%, 3.3 \%$, and $22.6 \mathrm{ppm})$ (Table 6$)$. The total tissue $\mathrm{N}$ concentration was (2.6\%), slightly lower than the ranges of Mills and Jones (1996) for corn at ear-leaf growth stage for conventional-till treatment. However total $\mathrm{N}$ concentration was within the sufficiency range (2.7\%) for no-till treatment at the ear-leaf growth stage. The total tissue $\mathrm{P}$ and $\mathrm{K}$ concentration was sufficient $(0.26 \%, 1.7 \%$ respectively) for corn at ear-leaf growth stage for conventional-till treatment. The total tissue $\mathrm{P}$ and $\mathrm{K}$ concentration was sufficient $(0.28 \%, 1.7 \%$ respectively) for corn at ear-leaf growth stage for the no-till treatment. The total tissue Zn concentration was slightly lower (15.3 ppm) than the average range for corn at ear-leaf growth stage for conventional-till treatment. The total tissue Zn concentration was slightly lower (14.3 ppm) than the sufficiency range for corn at ear-leaf growth stage for no-till treatment cross all tillage treatments. Cooler than normal soil conditions in the early part of the growing season probably slowed the diffusion rate of nutrients that move by mass flow such as $\mathrm{P}, \mathrm{K}$, and $\mathrm{Zn}$ and lowered tissue concentration. Overall, there were no significant differences in the plant nutrient concentration of $\mathrm{P}, \mathrm{K}$, and $\mathrm{Zn}$ between tillage treatments. Because tissue $\mathrm{P}, \mathrm{K}$, 


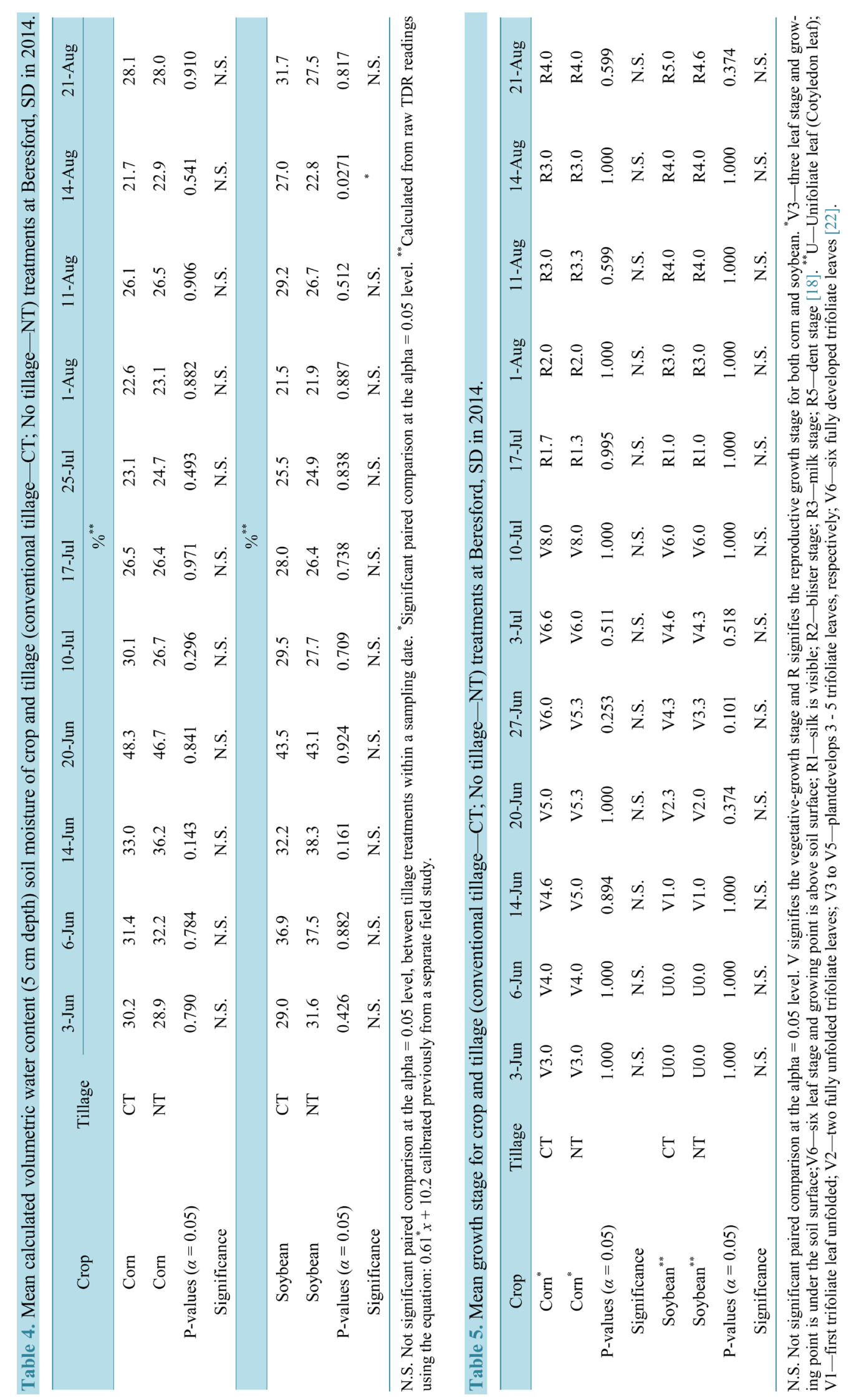




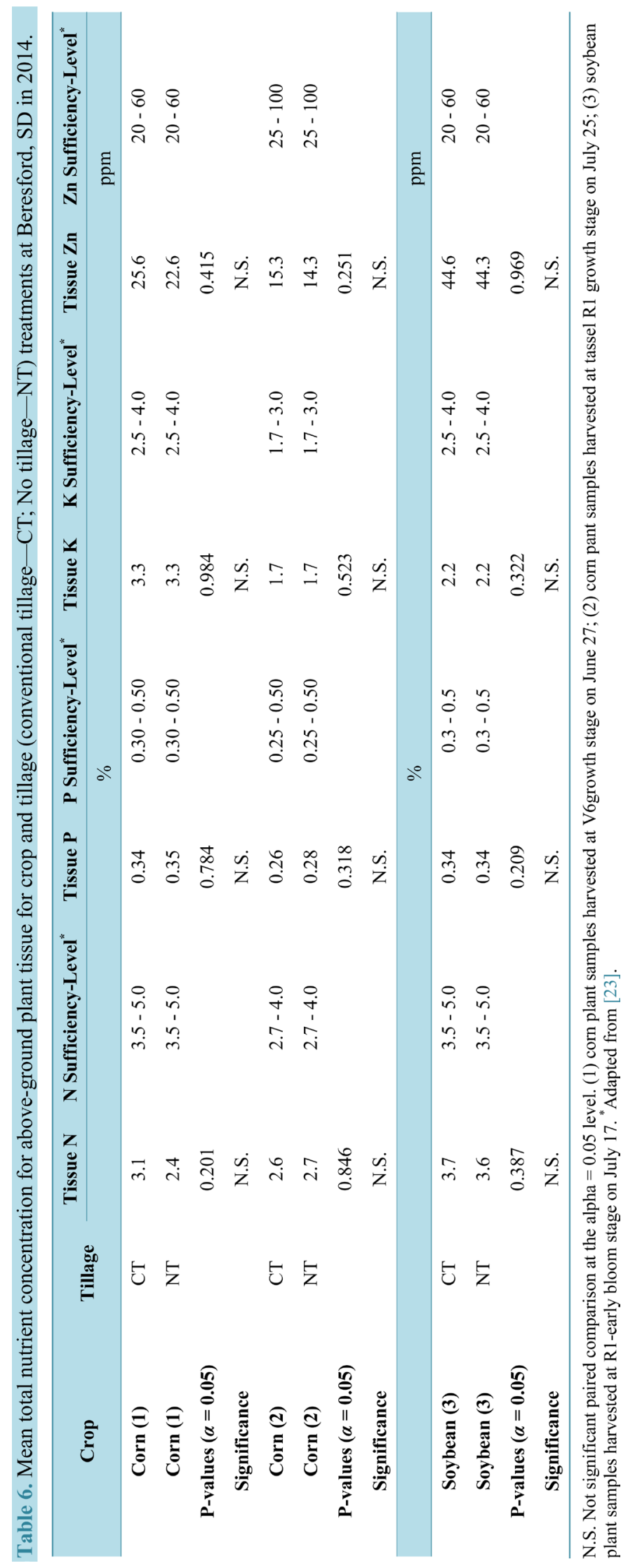


and $\mathrm{Zn}$ were similar between tillage treatments, these nutrients were available at similar levels in both tillage systems in the early part of the growing season. These results could have been much different in a drier season where the average temperature could also have been greater and growth stimulated to a greater extent in the conventional-till treatment.

The total tissue N, P, and Zn-nutrient concentration was sufficient (3.7\%, 0.34\%, and $44.6 \mathrm{ppm}$ ) for soybean at R1 growth stage [22], for conventional-till treatment across all tillage treatments. The total tissue $\mathrm{N}$, P, and Zn-nutrient concentration, was sufficient (3.6\%, 0.34\%, $44.6 \mathrm{ppm}$ ) for soybean at R1 growth stage for no-till treatment across all tillage treatments. The total tissue $\mathrm{K}$ concentration was deficient by $2.2 \%$ vs. the sufficiency level $(2.5 \%-4.0 \%)$ for soybean at R1 growth stage across all tillage treatments, according to [23] (Table 7). There was no significant difference in the plant nutrient concentration between tillage treatments. These results could have been much different in a warmer season where growth could have been stimulated to a greater extent.

\subsection{Grain Yield}

The mean corn grain yield for the conventional-till treatment $\left(10,311 \mathrm{~kg} \cdot \mathrm{ha}^{-1}\right)$ was only slightly greater than the yield of the no-till treatment $\left(10,123 \mathrm{~kg} \cdot \mathrm{ha}^{-1}\right)$ and was not significant (Table 7). In addition, the corn grain yield for the conventional-till treatment was less than the four year average $\left(10,311 \mathrm{~kg} \cdot \mathrm{ha}^{-1} \mathrm{vs} \cdot 11,121 \mathrm{~kg} \cdot \mathrm{ha}^{-1}\right.$ respectively), but statistics were not applied to the comparison. The lower grain yield compared to the four-year average reflected the probable lower yield potential due to the cooler early weather compared to a longer term average. The yield of the no-till treatment was slightly greater than the four-year average $\left(10,123 \mathrm{~kg} \cdot \mathrm{ha}^{-1} \mathrm{vs} .9966\right.$ $\mathrm{kg} \cdot \mathrm{ha}^{-1}$ respectively). The cooler than average weather conditions did not impact the yield potential, which was similar to the four-year average yield. The lack of an effect of tillage on corn grain yield somewhat agreed with the research of [6]. They reported that the mean corn grain yield differences between conventional-till and no-till was within $125 \mathrm{~kg} \cdot \mathrm{ha}^{-1}$ and was not significant. Corn grain yields between conventional-till and no-till in this study were within $200 \mathrm{~kg} \cdot \mathrm{ha}^{-1}$.

The mean soybean grain yield $\left(3961 \mathrm{~kg} \cdot \mathrm{ha}^{-1}\right)$ for the conventional-till treatment was greater than the yield of the no-till treatment (3295 $\mathrm{kg} \mathrm{ha}^{-1}$ ) but was not significant (Table 7). The soybean grain yield for conventional-till treatment was less than the four-year average (3961 kg.ha-1 vs. $3550 \mathrm{~kg} \cdot \mathrm{ha}^{-1}$, respectively). The lower yield reflected the cooler early season weather, which probably reduced the yield potential. The yield of no-till was similar to the yield of the four-year average (3295 kg.ha-1 vs. $3362 \mathrm{~kg} \cdot \mathrm{ha}^{-1}$, respectively). The cooler than average weather conditions and lower than normal GDD (Table 1) of 2014 did not impact the yield potential of the no-till treatment compared to the four-year average of the region. Soybean grain yield differences between conventional-till and no-till in this study were $665 \mathrm{~kg} \cdot \mathrm{ha}^{-1}$, but were not significant. Unlike the corn response, the difference in soybean grain yield between tillage treatments in this study was somewhat different than the research results of [7]. They reported that the mean soybean grain yield different between conventional-till and no-till was similar, about $200 \mathrm{~kg} \cdot \mathrm{ha}^{-1}$. Soils and growing season conditions probably played a role in these response differences.

\subsection{Grain Nutrient Removal}

The mean corn grain nutrient concentration for $\mathrm{P}, \mathrm{K}$, and $\mathrm{Zn}$ was $0.24 \%, 0.32 \%$, and $12.2 \mathrm{ppm}$, respectively, for the conventional-till treatment (Table 8). The corn grain nutrient concentration for $\mathrm{P}, \mathrm{K}$, and $\mathrm{Zn}$ was $0.22 \%$, $0.31 \%$, and $11.6 \mathrm{ppm}$ respectively for the no-till treatment. The difference in corn grain $\mathrm{P}, \mathrm{K}$, and $\mathrm{Zn}$, content was not significant different between tillage treatments.

The mean soybean grain nutrient concentration for $\mathrm{P}, \mathrm{K}$, and $\mathrm{Zn}$ was $0.50 \%, 1.66 \%$, and $31.3 \mathrm{ppm}$, respectively, for the conventional-till treatment. The soybean grain nutrient concentration for $\mathrm{P}, \mathrm{K}$, and $\mathrm{Zn}$ was $0.54 \%$, $1.70 \%$, and $33.4 \mathrm{ppm}$, respectively for the no-till treatment. The difference in soybean grain nutrient concentration for P and Zn was not significant different between tillage treatments. However P, nutrient was significantly different within the conventional-till treatment. This indicated that nutrient uptake to the grain was not influenced by tillage.

\subsection{Plant Tissue Nutrients in Crop Residue}

The mean nutrient concentration of corn residue for $\mathrm{P}, \mathrm{K}$, and $\mathrm{Zn}$ was $0.05 \%$, 0.85\%, and $13.20 \mathrm{ppm}$ respectively, 
for the conventional-till treatment (Table 9). The residue nutrient concentration for $\mathrm{P}, \mathrm{K}$, and $\mathrm{Zn}$ was $0.04 \%$, $0.91 \%, 14.43 \mathrm{ppm}$, respectively, for the no-till treatment.

The mean nutrient concentration of soybean residue for $\mathrm{P}, \mathrm{K}$, and $\mathrm{Zn}$ was $0.08 \%, 1.14 \%$, and $32.67 \mathrm{ppm}$ respectively for the conventional-till treatment. The nutrient concentration of soybean residue for $\mathrm{P}, \mathrm{K}$, and $\mathrm{Zn}$ was

Table 7. Mean grain yield for crop and tillage (conventional tillage-CT; No tillage-NT) treatments at Beresford, SD comparing 2014 yield to the mean of 2010-2013 yield.

\begin{tabular}{cccc}
\hline & & & Mean \\
\hline Filed Crop & Tillage & Grain Yield 2014 & Grain Yield 2010-2013 \\
\hline Corn & & $\mathrm{kg} \cdot \mathrm{ha}^{-1}$ & 11,121 \\
Corn & $\mathrm{CT}$ & 10,311 & 9966 \\
P-values $(\alpha=0.05)$ & $\mathrm{NT}$ & 10,123 & 3550 \\
Significance & & 0.803 & 3362 \\
Soybean & & N.S. & 3961 \\
Soybean & $\mathrm{CT}$ & 3295 & 0.167 \\
P-values $(\alpha=0.05)$ & $\mathrm{NT}$ & N.S. & \\
Significance & & &
\end{tabular}

N.S. Not significant paired comparison at the alpha $=0.05$ level.

Table 8. Mean grain nutrient concentration of crop and tillage (conventional tillage-CT; No tillage-NT) treatments at Beresford, SD in 2014.

\begin{tabular}{|c|c|c|c|c|}
\hline \multirow{2}{*}{ Crop } & \multirow{2}{*}{ Tillage } & $\mathrm{P}$ & $\mathrm{K}$ & \multirow{2}{*}{$\begin{array}{c}\mathrm{Zn} \\
\mathrm{ppm}\end{array}$} \\
\hline & & \multicolumn{2}{|c|}{$\%$} & \\
\hline Corn & $\mathrm{CT}$ & 0.24 & 0.32 & 12.2 \\
\hline Corn & NT & 0.22 & 0.31 & 11.6 \\
\hline P-values $(\alpha=0.05)$ & & 0.295 & 0.802 & 0.230 \\
\hline Significance & & N.S. & N.S. & N.S. \\
\hline Soybean & CT & 0.50 & 1.66 & 31.3 \\
\hline Soybean & NT & 0.54 & 1.70 & 33.4 \\
\hline P-values $(\alpha=0.05)$ & & 0.014 & 0.090 & 0.155 \\
\hline Significance & & * & N.S. & N.S. \\
\hline
\end{tabular}

N.S. Not significant paired comparison at the alpha $=0.05$ level. ${ }^{~}$ Significant paired comparison at the alpha $=0.05$ level.

Table 9. Mean crop residue nutrient concentration for crop and tillage (conventional tillage-CT; No tillage-NT) treatments at Beresford, SD in 2014.

\begin{tabular}{|c|c|c|c|c|}
\hline \multirow{2}{*}{ Crop } & \multirow{2}{*}{ Tillage } & $\mathrm{P}$ & $\mathrm{K}$ & \multirow{2}{*}{$\begin{array}{c}\mathrm{Zn} \\
\mathrm{ppm}\end{array}$} \\
\hline & & \multicolumn{2}{|c|}{$\%$} & \\
\hline Corn & $\mathrm{CT}$ & 0.05 & 0.85 & 13.20 \\
\hline Corn & NT & 0.04 & 0.91 & 14.43 \\
\hline P-values $(\alpha=0.05)$ & & 0.408 & 0.796 & 0.329 \\
\hline Significance & & N.S. & N.S. & N.S. \\
\hline Soybean & CT & 0.08 & 1.14 & 32.67 \\
\hline Soybean & NT & 0.08 & 0.97 & 44.80 \\
\hline P-values $(\alpha=0.05)$ & & 0.539 & 0.026 & 0.327 \\
\hline Significance & & N.S. & $*$ & N.S. \\
\hline
\end{tabular}

N.S. Not significant paired comparison at the alpha $=0.05$ level. "Significant paired comparison at the alpha $=0.05$ level. 
Table 10. Mean dry weight for stover and residue of crop and tillage (conventional tillage-CT; No tillage-NT) treatments at Beresford, SD in 2014.

\begin{tabular}{ccc}
\hline Crop & Tillage & Dry Weight \\
Corn & CT & 3.36 \\
Corn & NT ${ }^{-1}$ & 2.86 \\
P-values $(\alpha=0.05)$ & & 0.394 \\
Significance & N.S. & 2.36 \\
Soybean & CT & 2.13 \\
Soybean & NT & 0.346 \\
P-values $(\alpha=0.05)$ & & N.S. \\
\hline
\end{tabular}

N.S. Not significant paired comparison at the alpha $=0.05$ level.

$0.08 \%, 0.97 \%, 44.80 \mathrm{ppm}$, respectively for the no-till treatment.

When comparing the mean nutrient concentration of corn residue for conventional-till to the no-till treatment, the nutrient differences for $\mathrm{P}, \mathrm{K}$, and $\mathrm{Zn}$ levels were $+0.01 \%,-0.06 \%$, and $-1.2 \mathrm{ppm}$, respectively for the specific nutrient. Similar to the other tissue nutrient levels, the difference in corn residue nutrient concentration was not significantly different between tillage treatments.

When comparing the mean nutrient concentration of soybean residue for conventional-till to no-till treatment, the nutrient differences for $\mathrm{P}, \mathrm{K}$, and $\mathrm{Zn}$ levels were $+0.00 \%,-0.17 \%$, and $-12.13 \mathrm{ppm}$, respectively for the specific nutrient. The difference in soybean residue nutrient concentration for $\mathrm{P}$ and $\mathrm{Zn}$ was not significant between tillage treatments. However, the K nutrient levels were significantly different between the tillage treatments.

\subsection{Stover and Crop Residue Dry Weight}

The mean corn residue dry weight for conventional-till treatment was greater $\left(3.36 \mathrm{~kg} \cdot \mathrm{plot}^{-1}\right)$ than that $(2.86$ $\mathrm{kg} \cdot \mathrm{plot}^{-1}$ ) of the no-till treatment (Table 10). However this 15\% difference for the no-till treatment was not statistically different than the conventional-till treatment weight. The mean soybean crop residue dry weight for conventional treatments of $2.36 \mathrm{~kg} \cdot \mathrm{plot}^{-1}$ was greater than the $2.13 \mathrm{~kg} \cdot \mathrm{plot}^{-1}$ in the no-till treatment. However, the $10 \%$ difference was not statistically different between tillage treatments.

\section{Conclusion}

The precipitation in the early growing season was higher than normal (30-year average) and air temperature in the early part of the growing season was lower than normal in June 2014. This influenced the GDD's which were lower than normal in the early part of the growing season. As the result, there was no significant difference in soil temperature ( $5 \mathrm{~cm}$ depth) between tillage treatments in the early part of the growing season, removing the advantage of tillage for increasing early season soil temperatures. In the middle of the growing season, growth stages of the conventional-till treatments were slightly more advanced than the no-till treatments, but were not significantly different. The grain yields and nutrient removal were not influenced by tillage treatment. The growth and grain parameters of crops growing in the conventional-till treatment were suppressed due to the lower than normal air temperature and higher than normal soil moisture content during the early part of the growing season. This provided roughly equivalent growing environment for plants growing in the conventional and no-till treatments. As a result, no differences in growth and yield parameters of the crop were observed between tillage treatments. A warmer and a drier growing season would probably have shown a significant difference in soil temperature, soil moisture, dry matter production, nutrient concentration, and grain yield between tillage treatments.

\section{References}

[1] Wilhelm, W.W. and Wortmann, C.S. (2004) Tillage and Rotation Interaction for Corn and Soybean Grain Yield as Affected by Precipitation and Air Temperature. Agronomy Journal, 96, 425-432.

http://dx.doi.org/10.2134/agronj2004.0425 
[2] Kravechenko, G.A. and Thelen, K.D. (2007) Effect of Winter Wheat Crop Residue on No-Till Corn Growth and Development. Agronomy Journal, 99, 540-555.

[3] He, J., Li, H., Kuhn, N.J., Wang, Q. and Zhang, X. (2010) Effect of Ridge-Tillage, No-Tillage, and Conventional Tillage on Soil Temperature, Water Use, and Crop Performance in Cold and Semi-Arid Areas in Northeast China. Australian Journal of Soil Research, 48, 737-744. http://dx.doi.org/10.1071/SR09155

[4] Govaerts, B., Sayre, K.D., Goudeseune, B., Corte, P.D., Lichter, K., Dendooven, L. and Deckers, J. (2009) Conservation Agriculture as a Sustainable Option for the Central Mexican Highlands. Soil and Tillage Research, 103, 222-230. http://dx.doi.org/10.1016/j.still.2008.05.018

[5] Schwartz, R.C., Baumhardt, R.L. and Evett, S.R. (2010) Tillage Effects on Soil Water Redistribution and Bare Soil Evaporation Throughout a Season. Soil and Tillage Research, 110, 221-229. http://dx.doi.org/10.1016/j.still.2010.07.015

[6] Licht, M.A. and Al-Kaisi, M. (2004) Strip-Tillage Effect on Seedbed Soil Temperature and Other Soil Physical Properties. Soil and Tillage Research, 80, 233-249. http://dx.doi.org/10.1016/j.still.2004.03.017

[7] Chen, Y., Liu, S., Li, H., Li, X.F., Song, C.Y., Cruse, R.M. and Zhang, X.Y. (2011) Effects of Conservation Tillage on Corn and Soybean Yield in the Humid Continental Climate Region of Northeast China. Soil and Tillage Research, 115-116, 56-61. http://dx.doi.org/10.1016/j.still.2011.06.007

[8] Franzen, D.W., Overstreet, L.F., and Cattanach, N. (2007) NDSU Campus Tillage Trials, Year 4. Production Practices. Sugar Beet Res. and Ed. Board, 38, 119-123. N.D.S.U. http://www.sbreb.org/research/prod/prod07/Campustill07.pdf

[9] USDA-NRCS (2012) Web Soil Survey. USDA-NRCS, Washington DC. http://websoilsurvey.nrcs.usda.gov/app/WebSoilSurvey.aspx

[10] Gelderman, R. and Beegle, D. (1998) Nitrate-Nitrogen. In: Brown, J.R., Ed., Recommended Chemical Soil Test Procedures for the North Central Region, N.C.R. Pub. 221 (Revised), 17-20.

[11] Bouyoucos, G.J. (1962) Hydrometer Method Improved for Making Particle Size Analysis of Soils. Agronomy Journal, 54, 464-465. http://dx.doi.org/10.2134/agronj1962.00021962005400050028x

[12] Combs, S.M. and Nathan, M.V. (1998) Soil Organic Matter. In: Brown, J.R., Ed., Recommended Chemical Soil Test Procedures for the North Central Region, NCR Publication No. 221, Missouri Agricultural Experiment Station, Columbia, MO, 53-58.

[13] Watson, M.E. and Brown, J.R. (1998) pH and Lime Requirement. In: Brown, J.R., Ed., Recommended Chemical Soil Test Procedures for the North Central Region, NCR Publication No. 221, Missouri Agricultural Experiment Station, Columbia, MO, 13-16.

[14] Watanabe, F.S. and Olsen, S.R. (1965) Test of an Ascorbic Acid Method for Determining Phosphorus in Water and $\mathrm{NaHCO}_{3}$ Extracts from the Soil. Soil Science Society of America Journal, 29, 677-678. http://dx.doi.org/10.2136/sssaj1965.03615995002900060025x

[15] Frank, K., Beegle, D. and Denning, J. (1998) Phosphorus. In: Brown, J.R., Ed., Recommended Chemical Soil Test Procedures for the North Central Region, NCR Publication No. 221, Missouri Agricultural Experiment Station, Columbia, MO, 21-30.

[16] Warncke, D. and Brown, J.R. (1998) Potassium and Other Basic Cations. In: Brown, J.R., Ed., Recommended Chemical Soil Test Procedures for the North Central Region, NCR Publication No. 221, Missouri Agricultural Experiment Station, Columbia, MO, 31-33.

[17] Whitney, D.A. (1998) Micronutrients: Zinc, Iron, Manganese and Copper. In: Brown, J.R., Ed., Recommended Chemical Soil Test Procedures for the North Central Region, NCR Publication No. 221, Missouri Agricultural Experiment Station, Columbia, MO, 41-44.

[18] McWilliams, D.A., Berglund, D.R. and Endres, G.J. (1999) Corn Growth and Management Quick Guide. North Dakota Cooperative Extension Service, Fargo, 1-8.

[19] Sah, R.N. and Miller, R.O. (1992) Spontaneous Reaction for Acid Dissolution of Biological Tissues in Closed Vessels. Analytical Chemistry, 64, 230-233. http://dx.doi.org/10.1021/ac00026a026

[20] de Mendiburu, F. (2013) Statistical Procedures for Agricultural Research. Package “Agricolae” Version 1.4-4. Comprehensive R Archive Network, Institute for Statistics and Mathematics, Vienna. http://cran.r-project.org/web/packages/agricolae/agricolae.pdf

[21] Gerwing, J. and Gelderman, R. (2005) Fertilizer Recommendations Guide. South Dakota Cooperative Extension Service, South Dakota State University and USDA Cooperating, Brookings, SD, 8-20.

[22] Pedersen, P. (2004) Soybean Growth and Development. Iowa State University Extension Document PM 1945, 1-27. http://extension.agron.iastate.edu/soybean/documents/SoybeanGrowthandDevelopment.pdf

[23] Mills, H.A. and Benton Jones Jr., J. (1996) Plant Analysis Handbook II. Micro-Macro Publishing Inc., Jefferson, MO, 187-191. 